Review Article

DOI: $10.36959 / 395 / 513$

\title{
COVID-19 in Children: A Narrative Review
}

\author{
Jennifer F Ha, MBBS (Hons), FRACS ${ }^{1,2,3 *}$
}

${ }^{1}$ Department of Paediatrics Otolaryngology Head \& Neck Surgery, Perth Children's Hospital, Western Australia, Australia ${ }^{2}$ Murdoch ENT, Wexford Medical Center, Western Australia, Australia

${ }^{3}$ Department of Surgery, University of Western Australia, Stirling Highway, Australia

\begin{abstract}
Introduction: The coronavirus disease 2019 (COVID-19) pandemic is the third known zoonotic coronavirus. It is a disease that does not spare any age group.

There has been a tsunami of information since January. This review aims to summarise pertinent information relating to COVID-19 in children.

Method: A literature search was conducted on the PubMed, MedLine, and Embase databases, with the keyword "COVID-19" and "children". Bibliographic search was also undertaken. The abstracts were scanned to assess their appropriateness to be included in this narrative review. This was updated on the 11th April.
\end{abstract}

Result: The aetiology, transmission, incubation, pathophysiology, clinical features and complications, and management are discussed.

Conclusion: Our understanding of COVID-19 is evolving, as more reports are published. Continued research to understand its effect in children is important to help us manage the disease in these vulnerable population in a timely fashion.

\section{Keywords}

COVID-19, Review, Children, Asymptomatic, Kids, Infants, Neonates, SARS-CoV-2

\section{Introduction}

The coronavirus disease 2019 (COVID-19) pandemic is caused by the severe acute respiratory syndrome coronavirus 2 (SARS-CoV-2). It is the third known zoonotic coronavirus, after SARS-CoV-1 in 2003 and Middle East respiratory syndrome (MERS) in 2012. It is a disease that does not spare any age group.

There has been a tsunami of information since January. This review aims to summarise pertinent information relating to COVID-19 in children.

\section{Method}

A literature search was conducted on the PubMed, MedLine, and Embase databases, with the keyword "COVID 19" and "children". Bibliographic search was also undertaken. The abstracts were scanned to assess their appropriateness to be included in this narrative review. This was updated on the $11^{\text {th }}$ April.

\section{Results}

\section{Aetiology}

SARS-CoV-2 is an enveloped single-stranded RNA virus, of subgenus Sarbecovirus of the genus $\beta$-coronavirus [1]. The RNA is $29903 \mathrm{bp}$ in length [1]. It is approximately $60-140 \mathrm{~nm}$ in size $[1,2]$. It has high sequence similarity to the Guangdong pangolin coronaviruses, which may be an intermediate host of the virus before transmission to human [1]. Tang, et al. found two subtypes: $L(\sim 70 \%)$ type, which is derived from the $S(\sim 20 \%)$ type [3]. L type is more prevalent, replicates faster and accumulates more mutations, resulting in a higher transmission rate, therefore is likely to be more aggressive [3].

SARS-CoV-2-S uses the SARS-coronavirus receptor, angiotensin converting enzyme 2 (ACE2) for entry into host cells, which is a surface molecule highly expressed in type 2 alveolar cells of lung, as well as the oesophageal upper epithelial cells, absorptive enterocytes of the ileum and colon [1]. The

*Corresponding author: Jennifer F Ha, Murdoch ENT, Wexford Medical Center, Suite 17-18, Level 1, 3, Barry Marshall Parade, Murdoch 6150, Western Australia, Australia, Tel: +61-93407178, Fax: +61-9340-8693

Accepted: February 20, 2021

Published online: February 22, 2021

Citation: Ha JF (2021) COVID-19 in Children: A Narrative Review. Clin Pediatr Res 5(1):82-88

Copyright: (C) 2020 HA JF. This is an open-access article distributed under the terms of the Creative Commons Attribution License, which permits unrestricted use, distribution, and reproduction in any medium, provided the original author and source are credited. 
ACE2 expression is higher in the Asian population, and in the men [1].

\section{Transmission}

The transmission is reported to be between 1.5 and 4 cases per exposure [4-12].

Respiratory droplet $(5-50 \mu \mathrm{m})$ is the main route of transmission, which is affected by gravity, and may cause direct transmission via close contact, or surface contamination $[2,4,5,13-20]$. Large droplets ( $>5 \mu \mathrm{m}$ ) produced by coughing or sneezing fall rapidly to the ground [21]. SARS-CoV-2 can remain infectious on inanimate surfaces at room temperature for up to 9 days [22]. It is more stable on plastic and stainless steel than copper and cardboard [23]. It is detected up to 72 hours after application onto plastic, though the viral titre decayed exponentially [23]. The viral half-life was 6.8 hours on plastic, and 5.6 hours on stainless steel [23].

SARS-CoV-2 is highly contagious and can be transmitted via smaller aerosols with a droplet nuclei $\leq 5 \mu \mathrm{m}$, which can travel long distances and remain airborne for 2-4 hours, depending on the ambient conditions $[8,21]$. The particle size determines the location in the respiratory tract it is deposited when inhaled [21]. Certain events (e.g; coughing or sneezing, cardiopulmonary resuscitation) and aerosol generating procedures (AGP) (e.g; intubation, tracheostomy) can generate aerosols composed of smaller virus containing particles suspended in air [19]. Prolonged exposure to high concentrations of aerosols in a closed environment may facilitate transmission due to increased density of the viruses per unit volume [12].

Yung CF found no polymerase chain reaction (PCR) -detectable virus on the personal protective equipment (PPE) of the healthcare worker ( $\mathrm{HCW}$ ) caring for an asymptomatic infant with high viral load, with a total time spent of 15 minutes caring for the infant. The surrounding environment (bedding, cot rail and table one metre away) was found to have PCR-detectable virus [24].

Other mode of transmission reported include faecal-oral route as SARS-CoV-2 nucleic acid has been detected in the stool samples of COVID-19 patients with abdominal symptoms $[4,20,25]$.

Currently there is no direct evidence of vertical transmission. Suspected vertical transmission has been reported in a 36-hour newborn who was delivered via emergency caesarean section to a COVID-19 mother who was wearing N95 respirator during the delivery and had no contact with the neonate [26]. In addition, Zeng L, et al. report of three infected neonates born to COVID-19 mothers [27]. The possibility further been raised as immunoglobulin $M$ antibodies have been detected in newly born infants, although viral RNA has not been isolated [28]. However, several studies tested for the presence of SARS-CoV-2 in amniotic fluid, umbilical cord blood, breast milk samples at first lactation and neonatal pharyngeal swab but did not detect the virus.

\section{Incubation}

The incubation period is 3 to 7 days: The shortest being 1 day, and longest 24 days [11,12,29-33].

It is contagious during the latency period $[8,15,16,34-38]$. Shedding is greatest during the early phase of disease $[16,39]$. Viral load is highest in the first week (peaks at three to 5 days) after symptoms begin and decline over the second week, especially in the nose than throat [5,40-43]. The viral load in asymptomatic patients has been found to be similar to symptomatic patients $[15,40,44,45]$.

Prolonged viral shedding after recovery has also been reported, with reports up to 22 days $[11,12,20,37,43,46,47]$. Stool sample has been were found to be positive for a prolonged period, up to 18-51 days after symptom onset $[11,25,43,48,49]$.

\section{Pathophysiology}

The $S$ protein on its surface reacts with the molecules of the ACE2 in the alveolar epithelium (mainly type 2 pneumocytes), resulting in alveolar damage $[50,51]$. In children the development and function of ACE2 is imperfect, and the intracellular response induced by ACE2 in alveolar epithelial cells is lower than in adults [51-54]. Children has higher ACE activities, from 4 to 13-years-old, before gradually decreasing till it reaches adult values [55].

The composition and functional responsiveness of the children's immune system (IS) may be the reason for the milder symptoms and prolonged incubation period [12,56]. The dominant innate immunity and the underdeveloped adaptive immune response results in a qualitatively different response to the SARS-CoV2 virus $[48,51,53,56]$. The IS does not mount an acute inflammatory response to SARS-CoV-2, contributing to the better outcome $[48,51,57]$. They have a lower prevalence of increased C-reactive protein (CRP) suggesting a milder immune response and thus less immune damage [25]. Lymphopenia which is a predominant feature in severe infection occurs due to a combination of viral particle induced cytoplastic damage and apoptosis [58]. It may not occur in children due to the relative immaturity of their immune system and differences in immune response compared to adults, with children maintaining normal white cell and lymphocyte counts $[58,59]$. CD4 are higher, while CD8 T lymphocytes are lower in children, which may be related to the development and atrophy of the thymus [55].

Children are susceptible to a variety of viruses and the presence of the other simultaneous viruses in the airway mucosa, which may limit the growth of SARS-CoV-2 by direct interactions and competition, and the antibodies produced may cross-react with that of SARS-nCoV-2 to provide some protection, thus supporting the IS $[51,52,56]$. In addition, the frequent viral infections and vaccines in children may induce an enhanced state of activation of the innate IS, which result in more effective defence against different pathogens $[54,60]$. Bacillus Calmette-Guerin vaccine has been associated with heterologous immunity to other pathogens resulting in "trained immunity" involving innate cells like macrophages [61]. Lymphocytes count is high early in life and decreases later in childhood, and may also be higher due to frequently experienced viral infections [60]. In addition, they are gen- 
Table 1: Reported clinical symptoms in the literature.

\begin{tabular}{|c|c|}
\hline \multicolumn{2}{|l|}{ Symptoms } \\
\hline Fever & $36-80 \%$ \\
\hline Headache & $8-20 \%$ \\
\hline \multicolumn{2}{|l|}{ Myalgia } \\
\hline Fatigue & $5-7.6 \%$ \\
\hline $\begin{array}{l}\text { Cough } \\
\text { - } \text { Dry } \\
\text { - Expectoration }\end{array}$ & $\begin{array}{l}30-75 \% \\
19-44 \% \\
50 \%\end{array}$ \\
\hline Nasal obstruction/congestion & $5.3-30 \%$ \\
\hline Rhinorrhoea & $7.6-20 \%$ \\
\hline Sneezing & $20 \%$ \\
\hline Dyspnea & $3-100 \%$ \\
\hline Hypoxia (< $92 \%$ oxygen saturation) & $2.3 \%$ \\
\hline \multicolumn{2}{|l|}{ Wheezing } \\
\hline Pneumonia & $53 \%$ \\
\hline Sore Throat & $5-40 \%$ \\
\hline Tachycardia & $42.1 \%$ \\
\hline Abdominal discomfort/pain & $8 \%$ \\
\hline Nausea \& vomiting & $5-50 \%$ \\
\hline Diarrhea & $5-57.1 \%$ \\
\hline
\end{tabular}

erally healthier with less exposure to pollution and cigarette smoked resulting in in healthier respiratory tracts [61].

\section{Clinical presentation}

In Italy, children constitute $1.2 \%$ of the cases. In China, $2.16 \%$ are $\leq 18$-years-old with $<1 \%$ are $<10$-years-old $[58,62,63]$. In South Korea, where testing are done on a massive scale, $6.3 \%$ of the confirmed cases are $<20$-years-old $[25,48,56]$. In the US, it is $1.7 \%$ [64]. In Madrid, $0.8 \%$ are < 18-years-old [65].

The clinical course is generally milder in children than adults [2,12,31,32,43-46,48,51,66-72]. 2.5-10\% have severe disease, and $0.6 \%$ have critical disease; $10.6 \%$ are $<1$-yearold, $7.3 \% 1-5$ years, $4.2 \%$ 6-10 years, $4.1 \% 11-15$ years and $3 \%$ $16-17$ years $[29,58,71,73]$.

Some are asymptomatic (1.3-60\%), which may be an underestimation as they are not usually tested for obvious reasons $[12,25,33,43,45,47,48,58,63,64,74-77]$. Chan JF, et al. reported an asymptomatic 10 -year-old, who had ground class changes on lung computed tomography (CT), and high viral load in the sputum sample [15].

The reported clinical symptoms are shown in Table 1 $[25,31,47,63-65,70,76-78]$. The symptoms are variable and may be atypical. Children $\leq 5$-years-old are more likely to develop severe clinical manifestations due to the immaturity of the respiratory tract and immune system $[75,79]$. Respiratory distress occurs in premature infants and children with underlying chronic condition $[47,80]$. Apart from younger age, other risk factors for a more severe outcome include pulmonary
Table 2: Reported bloodwork findings in the literature.

\begin{tabular}{|c|c|}
\hline \multicolumn{2}{|l|}{ Bloodwork } \\
\hline White Cell Count & \\
\hline - Leucocytes: & $\begin{array}{l}\text { Normal } 69.6-70 \% \\
\text { Increase } 10-28.6 \% \\
\text { Decrease } 20-53.5 \%\end{array}$ \\
\hline - Neutrophils & $\begin{array}{l}\text { Lymphopenia 3-30.6\% } \\
\text { Neutrophilia } 4.6 \% \\
\text { Neutropenia } 6 \% \\
\text { Thrombocytosis } 14.3 \%\end{array}$ \\
\hline C-Reactive Protein & 个 $2.7-45 \%$ \\
\hline $\begin{array}{l}\text { Creatine Kinase } \\
\text { - Creatine Kinase MB }\end{array}$ & $\begin{array}{l}\uparrow 2.7 \% \\
\uparrow 25-75 \%\end{array}$ \\
\hline Alanine Aminotransferase & 个 $5.6 \%$ \\
\hline Aspartate Transferase & 个 $8.3 \%$ \\
\hline Procalcitonin & $\uparrow 10.6-80 \%$ \\
\hline D-Dimer & 个 8.3\% \\
\hline
\end{tabular}

pathology and immunocompromise [12,73]. Children with co-morbidities (hydronephrosis, leukemia and intussusception) are more likely to require mechanical ventilation [63]. Pneumonia may develop, and some may progress rapidly, resulting in respiratory failure within 1-3 days [81].

Bloodwork findings are summarised in Table 2 $[47,58,63,70]$. Most children have leucocytosis rather than the leucopenia found in adults [70]. The features that distinguish mild to the more severe disease are decrease in CD4 and CD8 T cell subsets, decrease in neutrophil-to-lymphocyte ratio, decrease lymphocytes $(p=0.008)$, raised body temperature $(p=0.002)$, elevated procalcitonin $(p=0.004)$, elevated $D$-dimer $(p=0.03)$, and creatine kinase MB $(p=0.008)$ $[25,43]$. High IL-6 levels are associated with increased mortality in < 5-years-old with severe pneumonia [58]. This trend follows CRP [58]. Procalcitonin is thought to be induced by bacteriotoxin but suppressed by interferon, and in children is associated with bacterial co-infection $(40 \%)[31,58]$. Some authors reported up to two third of the cases have viral co-infections [76].

Most children recover within 1 to 2 weeks $[29,32,43,51,68,70,74,82]$. Disease duration in those with severe disease is over 10 days, but in critically ill, over 20 days [62].

\section{Diagnosis}

Diagnosis is based on epidemiological history, clinical symptoms and laboratory tests.

Nucleic acid testing via real time reverse transcription PCR assay, or viral gene sequencing of throat swabs, sputum, stool or blood samples.

Chest X-ray (CXR) is usually non specific [61]. CT plays 
an important role in surveillance and diagnosis of COVID-19 pneumonia with higher sensitivity than CXR [10]. Children with mild disease does not routinely need CT chest due to the radiation exposure. Its sensitivity as diagnostic tool to detect COVID-19 pneumonia has been reported to be between 80 $100 \%[48,50]$.

CT findings are diverse from normal (20-50\%) to a few lesions including ground glass opacification (30-60\%), fine mesh shadow $(20 \%)$, tiny nodules $(15 \%)$, or consolidation with a surrounding halo $(50 \%)[10,29,31,49,63,70,77,78,83]$. The lesions are generally small nodular ground glass opacities or subpleural patchy opacities $[48,83]$. $20-60 \%$ have unilateral, while $20-70 \%$ bilateral involvement $[31,74,77,78]$. Despite CT findings of chest lesions, children can remain asymptomatic $(7.02 \%)[15,47,48]$.

\section{Complication}

While early reports from China are encouraging with only two deaths: 14-years-old (risk not elaborated) and a 10-months-old (intussusception and multi-organ failure 4 weeks after admission), there has been several reports so far [63].

Septic shock and multi organ failure are the most common complications in critically ill patients [62]. Others include toxic encephalopathy, status epilepticus, renal insufficiency, metabolic acidosis, cardiac insufficiency and coagulopathy [62]. Mortality is the main cause of death in < 5-years-old [25].

The higher rate of asymptomatic patients, the potentially prolonged shedding of virus in nasal secretion and stool have substantial implications of children in its transmission in day care, school and home $[25,43,73]$. It is hard for children to be aware of their personal hygiene, and if infected, they can result in cluster outbreaks. Schools closure early in outbreaks is believed to reduce transmission [84]. However, school closures may not only result in loss of education, but also negative effects on physical and mental health to be considered due to children being confined to their homes. This includes longer screen time, irregular sleep, nightmares, poor appetite, less healthy diet that results in weight gain, and a loss of cardiorespiratory fitness $[52,68,85]$.

The stocking up on shelf stable food as part of the preparedness results in a calorie dense diet in children [85]. There are others in whom free school meals are an important source of nutrition [84]. The increases in weight found to occur during summer recesses is reported to be maintained during the school year and accrues from summer to summer, with lasting effect even into adulthood [85]. Social distancing and stay at home orders may result in physical inactivity, especially those living in dense urban area [85].

Psychological impact may result from physical and social isolations, as well as stressors like fears, uncertainties, frustration, boredom, lack of in-person contact with peers, being exposed to large amount of information, high levels of stress and anxiety in adults around them, and family financial loss $[52,68,86]$. Children experience substantial changes to their daily routine and social infrastructure, which ordinarily foster resilience in challenging events [86]. Clinginess in the 3-6 years age group, and inattention, irritability and challenging externalising behaviours in the older age group are some of the psychological manifestations reported $[68,86]$. Some reports that harms to child welfare with violence and vulnerability increasing during periods of school closures associated with health emergencies [84,87]. Isolation or quarantine during pandemic have been reported to result in acute stress disorder, adjustment disorder and grief, with 30\% meeting clinical criteria of post-traumatic stress [88].

Another vulnerable group are those quarantined in hospitals, or have lost their caregivers due to COVID-19. Separation from caregivers may result in a state of crisis, increasing the risk of psychological disorders as companionship is essential for children's normal psychological development and wellbeing [88]. Separation from parents or parental loss during childhood is associated with a higher risk of developing mood disorders and psychosis, death by suicide in adulthood [88].

\section{Treatment}

The mainstay of treatment is symptomatic with respiratory support, and treatment of complications. Anti-virals may be helpful in severe cases: Virazole, oseltamivir, arbidol, ribavirin, lopinavir/ritonavir and interferon $[25,62,78]$. The data on efficacy is unavailable. Table 3 summarises the recommended treatment $[2,25,32,62,63,78,89]$.

IFN- $\alpha$ nebulisation has shown good safety profiles under most circumstances $[32,89,90]$. IFN- $\alpha$ spray has been used for high risk populations with close contact with suspected COVID positive patients or those in early phase with only upper respiratory tract symptoms [32]. The dose is one to two sprays into each nostrils, 8-10 sprays into the oropharynx for 5-7 days [32].

Children are sensitive to accumulation of chloroquine which may induce severe retinopathy, ototoxicity and cardiotoxicity [89].

Antibiotic, glucocorticoid and immunoglobulin therapies are used as indicated [78]. Steroid should be avoided but a short course (3-5 days of $1-2 \mathrm{mg} / \mathrm{kg} /$ day of methylprednisolone) can be considered in acute respiratory distress syndrome (ARDS), and other complications like toxic shock [2]. Intravenous immunoglobulin may be used in severe cases (1 $\mathrm{g} / \mathrm{kg} /$ day for 2 days, or $400 \mathrm{mg} / \mathrm{kg} /$ day for 5 days) [2].

During delivery, delayed cord clamping's benefit outweighs the unlikely risk of acquiring COVID-19 in suspected or confirmed COVID-19 mothers [28]. The optimal mode of nutrition of infant born to COVID-19 mother is unknown, and the benefits of breastfeeding should be weighed against the risk of transmission [28]. There have been no reports demonstrating SARS-CoV-2 in breastmilk.

For neonates with ARDS, high dose pulmonary surfactant, inhaled nitric oxide, high frequency oscillatory ventilation and extracorporeal membrane oxygenation have been recommended [30].

Children are attuned to adults' emotional states [86]. Strategies to nurture resilience include increasing communication with children to address their fears and concerns 
Table 3: Recommended treatment in the literature.

\begin{tabular}{|c|c|c|c|c|}
\hline Drugs & Mode of action & Recommended dosing & Precaution & Side effects \\
\hline IFN- $\alpha$ & $\begin{array}{l}\text { Broad spectrum } \\
\text { antiviral } \\
\text { Inhibit viral RNA } \\
\text { synthesis, viral } \\
\text { replication and } \\
\text { spread }\end{array}$ & $\begin{array}{l}\text { Nebulised } \\
\text { (mild cases) 100,000- } \\
200,000 \mathrm{IU} / \mathrm{kg} \text {, (severe } \\
\text { cases) } 200,000-4000,000 \\
\mathrm{IU} / \mathrm{kg} \text { or } 2-4 \mu \mathrm{g} / \mathrm{kg} \text { (in } 2 \\
\mathrm{~mL} \text { sterile water) } \\
\text { BD-TDS for } 5-7 \text { days }\end{array}$ & $\begin{array}{l}\text { Liver \& renal dysfunction, } \\
\text { mental illness (suicidal } \\
\text { ideation more common } \\
\text { in adolescents vs adults), } \\
\text { severe or unstable heart } \\
\text { disease or aplastic anaemia } \\
\text { Used with caution in < } \\
\text { 2-months-old }\end{array}$ & $\begin{array}{l}\text { Low grade fever, flu- } \\
\text { like symptoms, growth } \\
\text { suppression (when used } \\
\text { with ribavirin) } \\
\text { Overdose: } \\
\text { Myelosuppression, liver } \\
\text { dysfunction, renal failure, } \\
\text { coagulopathy }\end{array}$ \\
\hline Lopinavir/ritonavir & $\begin{array}{l}\text { Lopinavir is a } \\
\text { substrate of } \\
\text { CYP3A enzyme; } \\
\text { ritonavir is } \\
\text { a strong } \\
\text { inhibitor of } \\
\text { CYP3A enzyme }\end{array}$ & $\begin{array}{l}\text { Oral } \\
\leq 15 \mathrm{~kg}: 12 \mathrm{mg} / 3 \mathrm{mg} / \mathrm{kg} \\
\text { per dose } \\
\text { 15-40 kg: } 10 \mathrm{mg} / 2.5 \mathrm{mg} / \\
\mathrm{kg} \text { per dose } \\
\geq 40 \mathrm{~kg}: 400 \mathrm{mg} / 100 \mathrm{mg} \\
\text { per dose } \\
\text { BD for } 1-2 \text { weeks }\end{array}$ & $\begin{array}{l}\text { Liver dysfunction, jaundice, } \\
\text { increase PR interval, heart } \\
\text { blocks and hypokalemia } \\
\text { Contains } 42 \% \text { ethanol and } \\
15 \% \text { propylene glycol, which } \\
\text { is not recommended in }< \\
14-\text { days-old }\end{array}$ & Diarrhea, vomiting, rash \\
\hline Ribavirin & $\begin{array}{l}\text { Broad spectrum } \\
\text { antiviral with } \\
\text { inhibitory effects } \\
\text { on RNA \& DNA } \\
\text { viruses }\end{array}$ & $\begin{array}{l}\text { Intravenous: } \\
\text { 10-15 mg/kg per dose } \\
\text { (maximum of 500mg per } \\
\text { dose) } \\
\text { divided into BD-TDS } \\
\text { dosing }\end{array}$ & $\begin{array}{l}\text { Liver \& renal dysfunction, } \\
\text { cardiac disease } \\
\text { Not recommended < } \\
\text { 3-years-old orally }\end{array}$ & $\begin{array}{l}\text { Fever, headache, } \\
\text { neutropenia, fatigue } \\
\text { Overdose: Haemolytic } \\
\text { anaemia, myocardial injury }\end{array}$ \\
\hline Chloroquine Dipohsphate & Anti-malarial & No recommendation & $\begin{array}{l}\text { Liver \& renal dysfunction, } \\
\text { haematoprophyria, mental } \\
\text { illness. } \\
\text { Use with caution in children }\end{array}$ & $\begin{array}{l}\text { Dizziness, headache, loss } \\
\text { of appetite, ocular toxicity, } \\
\text { arrhythmia, psychosis, } \\
\text { leukopenia } \\
\text { Overdose: Fatal with a dose } \\
\text { of } 50 \mathrm{mg} / \mathrm{kg}\end{array}$ \\
\hline Arbidol & & No recommendation & $\begin{array}{l}\text { Liver dysfunction } \\
\text { Use with caution in children }\end{array}$ & $\begin{array}{l}\text { Nausea, dizziness, diarrhea, } \\
\text { elevated aminotransferase }\end{array}$ \\
\hline
\end{tabular}

(taking into account their age and level of understanding), playing collaborative games to alleviate loneliness, encourage activities that promote physical activities, using music therapy to reduce stress, fear and worry, improve sleep hygiene, relaxation therapy, model a positive psychological attitude to reduce stress $[68,86]$.

\section{Conclusion}

Our understanding of COVID-19 is evolving, as more reports are published. Continued research to understand its effect in children is important to help us manage the disease in these vulnerable population in a timely fashion.

\section{Competing Interests}

No relevant disclosures.

\section{Conflict of Interest}

None to declare.

\section{References}

1. Lu Q, Shi Y (2020) Coronavirus disease (COVID-19) and neonate: What neonatologist need to know. J Med Virol 92: 564-567.

2. Chen ZM, Fu JF, Shu Q, et al. (2020) Diagnosis and treatment rec- ommendations for pediatric respiratory infection caused by the 2019 novel coronavirus. World J Pediatr 16: 240-246.

3. Tang X, Wu C, Li X, et al. (2020) On the origin and continuing evolution of SARS-CoV-2. Natl Sci Rev 2020.

4. Wong J, Goh QY, Tan Z, et al. (2020) Preparing for a COVID-19 pandemic: A review of operating room outbreak response measures in a large tertiary hospital in Singapore. Can J Anaesth 67: 732-745.

5. Jin YH, Cai L, Cheng ZS, et al. (2020) A rapid advice guideline for the diagnosis and treatment of 2019 novel coronavirus (2019$\mathrm{nCoV}$ ) infected pneumonia (standard version). Military Medical Research 7: 4.

6. Liu Y, Li J, Feng Y (2020) Critical care response to a hospital outbreak of the 2019-nCoV infection in Shenzhen, China. Crit Care 24: 56.

7. Remuzzi A, Remuzzi G (2020) COVID-19 and Italy: What next? Lancet.

8. Han Q, Lin Q, Jin S, et al. (2020) Coronavirus 2019-nCoV: A brief perspective from the front line. J Infect 80: 373-377.

9. Jung SM, Akhmetzhanov AR, Hayashi K, et al. (2020) Real-time estimation of the risk of death from novel coronavirus (covid-19) infection: Inference using exported cases. J Clin Med 9: 523.

10. Liu H, Liu F, Li J, et al. (2020) Clinical and CT imaging features of 
the COVID-19 pneumonia: Focus on pregnant women and children. J Infect 80: e7-e13.

11. Cai J, Xu J, Lin D, et al. (2020) A Case Series of children with 2019 novel coronavirus infection: clinical and epidemiological features. Clin Infect Dis 71: 1547-1551.

12. Jiatong S, Lanqin L, Wenjun L. (2020) COVID-19 epidemic: Disease characteristics in children. J Med Virol 92: 747-754.

13. Li JO, Lam DSC, Chen Y, et al. (2020) Novel Coronavirus disease 2019 (COVID-19): The importance of recognising possible early ocular manifestation and using protective eyewear. Br J Ophthalmol 104: 297-298.

14. Schwartz J, King CC, Yen MY (2020) Protecting Health Care Workers during the COVID-19 Coronavirus Outbreak -Lessons from Taiwan's SARS response. Clin Infect Dis.

15. Chan JF, Yuan S, Kok KH, et al. (2020) A familial cluster of pneumonia associated with the 2019 novel coronavirus indicating person-to-person transmission: A study of a family cluster. Lancet 395: 514-523.

16. Yu P, Zhu J, Zhang Z, et al. (2020) A familial cluster of infection associated with the 2019 novel coronavirus indicating potential person-to-person transmission during the incubation period. J Infect Dis 221: 1757-1761.

17. Huh S (2020) How to train the health personnel for protecting themselves from novel coronavirus (COVID-19) infection during their patient or suspected case care. J Educ Eval Health Prof 17: 10.

18. (2020) Rational use of personal protective equipment (PPE) for coronavirus disease (COVID-19). WHO.

19. Brewster DJ, Chrimes NC, Do TB, et al. (2020) Consensus statement: Safe Airway Society principles of airway management and tracheal intubation specific to the COVID-19 adult patient group. Med J Aust 212: 472-481.

20. Zhang T, Cui X, Zhao X, et al. (2020) Detectable SARS-CoV-2 Viral RNA in Feces of Three Children during Recovery Period of COVID-19 Pneumonia. J Med Virol 92: 909-914.

21. Yassi A, Moore D, Fitzgerald JM, et al. (2005) Research gaps in protecting healthcare workers from SARS and other respiratory pathogens: An interdisciplinary, multi-stakeholder, evidence-based approach. J Occup Environ Med 47: 41-50.

22. Kampf G, Todt D, Pfaender S, et al. (2020) Persistence of coronaviruses on inanimate surfaces and their inactivation with biocidal agents. J Hosp Infect 104: 246-251.

23. Van Doremalen N, Bushmaker T, Morris DH, et al. (2020) Aerosol and surface stability of SARS-CoV-2 as compared with sars-cov-1. N Engl J Med 382: 1564-1567.

24. Yung CF, Kam KQ, Wong MSY, et al. (2020) Environment and personal protective equipment tests for sars-cov-2 in the isolation room of an infant with infection. Ann Intern Med 173: 240-242.

25. Qiu H, Wu J, Hong L, et al. (2020) Clinical and epidemiological features of 36 children with coronavirus disease 2019 (COVID-19) in Zhejiang, China: An observational cohort study. Lancet Infect Dis 20: 689-696.

26. Wang S, Guo L, Chen L, et al. (2020) A case report of neonatal COVID-19 infection in China. Clin Infect Dis 71: 853-857.

27. Zeng L, Xia S, Yuan W, et al. (2020) Neonatal early-onset infection with sars-cov- 2 in 33 neonates born to mothers with covid-19 in Wuhan, China. JAMA Pediatr 174: 722-725.

28. Chandrasekharan $P$, Vento $M$, Trevisanuto $D$, et al. (2020) Neonatal resuscitation and postresuscitation care of infants born to mothers with suspected or confirmed sars-cov-2 infection. Am J Perinatol 37: 813-824.
29. Ludvigsson JF (2020) Systematic review of COVID-19 in children shows milder cases and a better prognosis than adults. Acta Paediatr 109: 1088-1095.

30. Wang L, Shi Y, Xiao T, et al. (2020) Chinese expert consensus on the perinatal and neonatal management for the prevention and control of the 2019 novel coronavirus infection (First edition). Ann Transl Med 8: 47.

31. Xia W, Shao J, Guo Y, et al. (2020) Clinical and CT features in pediatric patients with COVID-19 infection: Different points from adults. Pediatr Pulmonol 55: 1169-1174.

32. Shen $K$, Yang $Y$, Wang T, et al. (2020) Diagnosis, treatment, and prevention of 2019 novel coronavirus infection in children: Experts' consensus statement. World J Pediatr 16: 223-231.

33. Tang A, Tong ZD, Wang HL, et al. (2020) Detection of novel coronavirus by RT-PCR in stool specimen from asymptomatic child, china. Emerg Infect Dis 26: 1337-1339.

34. Wax RS, Christian MD (2020) Practical recommendations for critical care and anesthesiology teams caring for novel coronavirus (2019-nCoV) patients. Can J Anaesth 67: 568-576.

35. Zhang H (2020) Early lessons from the frontline of the 2019nCoV outbreak. Lancet 395: 687.

36. Koh D (2020) Occupational risks for COVID-19 infection. Occup Med (Lond) 70: 3-5.

37. Rothe C, Schunk M, Sothmann P, et al. (2020) Transmission of 2019-nCoV infection from an asymptomatic contact in germany. N Engl J Med 382: 970-971.

38. Mizumoto K, Chowell G (2020) Estimating risk for death from 2019 novel coronavirus disease, china, january-february 2020. Emerg Infect Dis 26.

39. Bedford J, Enria D, Giesecke J, et al. (2020) COVID-19: Towards controlling of a pandemic. Lancet 395: 1015-1018.

40. Zou L, Ruan F, Huang M, et al. (2020) SARS-CoV-2 viral load in upper respiratory specimens of infected patients. N Engl J Med 382: 1177-1179.

41. (2020) Guidance for health care workers performing aerosol generating medical procedures during the COVID-10 pandemic. CSO-HNS.

42. (2020) Handbook of COVID-19 prevention and treatment. Zhejiang University.

43. Cao Q, Chen YC, Chen CL, et al. (2020) SARS-CoV-2 infection in children: Transmission dynamics and clinical characteristics. J Formos Med Assoc 119: 670-673.

44. Kam KQ, Yung CF, Cui L, et al. (2020) A well infant with coronavirus disease 2019 (covid-19) with high viral load. Clin Infect Dis 71: 847-849.

45. Qian G, Yang N, Ma AHY, et al. (2020) A COVID-19 transmission within a family cluster by presymptomatic infectors in china. Clin Infect Dis 71: 861-862.

46. Lin J, Duan J, Tan T, et al. (2020) The isolation period should be longer: Lesson from a child infected with SARS-CoV-2 in Chongqing, China. Pediatr Pulmonol 55: E6-E9.

47. Guan WJ, Ni ZY, Hu Y, et al. (2020) Clinical characteristics of coronavirus disease 2019 in china. N Engl J Med 382: 1708-1720.

48. Park JY, Han MS, Park KU, et al. (2020) First pediatric case of coronavirus disease 2019 in korea. J Korean Med Sci 35: e124.

49. Cui Y, Tian M, Huang D, et al. (2020) A 55-day-old female infant infected with covid 19: Presenting with pneumonia, liver injury, and heart damage. J Infect Dis 221: 1775-1781.

50. Wujtewicz M, Dylczyk-Sommer A, Aszkiełowicz A, et al. (2020) COVID-19 - what should anaethesiologists and intensivists know 
about it? Anaesthesiol Intensive Ther 52: 34-41.

51. Li Y, Guo F, Cao Y, et al. (2020) Insight into COVID-2019 for pediatricians. Pediatr Pulmonol 55: E1-E4.

52. Wang G, Zhang Y, Zhao J, et al. (2020) Mitigate the effects of home confinement on children during the COVID-19 outbreak. Lancet 395: 945-947.

53. Su L, Ma X, Yu H, et al. (2020) The different clinical characteristics of corona virus disease cases between children and their families in China - the character of children with COVID-19. Emerg Microbes Infect 9: 707-713.

54. Dong $\mathrm{Y}, \mathrm{Mo} \mathrm{X}, \mathrm{Hu} \mathrm{Y}$, et al. (2020) Epidemiology of COVID-19 among children in china. Pediatrics 145: e20200702.

55. Zhu L, Lu X, Chen L (2020) Possible causes for decreased susceptibility of children to coronavirus Pediatr Res 88: 342.

56. Brodin P (2020) Why is COVID-19 so mild in children? Acta Paediatr 109: 1082-1083.

57. Shen $Q$, Guo W, Guo T, et al. (2020) Novel coronavirus infection in children outside of Wuhan, China. Pediatr Pulmonol 55: 1424-1429.

58. Henry BM, Lippi G, Plebani M (2020) Laboratory abnormalities in children with novel coronavirus disease 2019. Clin Chem Lab Med 58: 1135-1138.

59. Yonker LM, Shen K, Kinane TB (2020) Lessons unfolding from pediatric cases of COVID-19 disease caused by SARS-CoV-2 infection. Pediatr Pulmonol 55: 1085-1086.

60. Cristiani L, Mancino E, Matera L, et al. (2020) Will children reveal their secret? The coronavirus dilemma. Eur Respir J.

61. Balasubramanian S, Rao NM, Goenka A, et al. (2020) Coronavirus Disease (COVID-19) in Children - What We Know So Far and What We Do Not? Indian Pediatr 57: 435-442.

62. Sun D, Li H, Lu XX, et al. (2020) Clinical features of severe pediatric patients with coronavirus disease 2019 in Wuhan: A single center's observational study. World J Pediatr 16: 251-259.

63. Lu X, Zhang L, Du H, et al. (2020) SARS-CoV-2 infection in children. N Engl J Med 382: 1663-1665.

64. CDC COVID-19 Response team (2020) Coronavirus Disease 2019 in Children - United States, February 12-April 2, 2020. MMWR Morb Mortal Wkly Rep 69: 422-426.

65. Tagarro A, Epalza C, Santos M, et al. (2020) Screening and severity of coronavirus disease 2019 (COVID-19) in children in madrid, spain. JAMA Pediatr e201346.

66. Ji LN, Chao S, Wang YJ, et al. (2020) Clinical features of pediatric patients with COVID-19: A report of two family cluster cases. World J Pediatr 16: 267-270.

67. Canarutto D, Priolo A, Russo G, et al. (2020) COVID-19 infection in a paucisymptomatic infant: Raising the index of suspicion in epidemic settings. Pediatr Pulmonol 55: E4-E5.

68. Jiao WY, Wang LN, Liu J, et al. (2020) Behavioral and emotional disorders in children during the COVID-19 epidemic. J Pediatr 221: 264-266.e1.

69. Le HT, Nguyen LV, Tran DM, et al. (2020) The first infant case of COVID-19 acquired from a secondary transmission in Vietnam. Lancet Child Adolesc Health 4: 405-406.

70. Han YN, Feng ZW, Sun LN, et al. (2020) A comparative-descriptive analysis of clinical characteristics in 2019-Coronavirus-infected children and adults. J Med Virol 92: 1596-1602.
71. Kamali Aghdam M, Jafari N, Eftekhari K (2020) Novel coronavirus in a 15-day-old neonate with clinical signs of sepsis, a case report. Infect Dis (Lond) 52: 427-429.

72. Morand A, Fabre A, Minodier P, et al. (2020) COVID-19 virus and children: What do we know? Arch Pediatr 27: 117-118.

73. Hagmann SHF (2020) COVID-19 in children: More than meets the eye. Travel Med Infect Dis 34: 101649.

74. Liu M, Song Z, Xiao K (2020) High-resolution computed tomography manifestations of 5 pediatric patients with 2019 novel coronavirus. J Comput Assist Tomogr 44: 311-313.

75. Kelvin AA, Halperin S (2020) COVID-19 in children: The link in the transmission chain. Lancet Infect Dis 20: 633-634.

76. T Cruz AT, Zeichner SL (2020) COVID-19 in children: Initial characterization of the pediatric disease. Pediatrics 145: e20200834.

77. Zhu L, Wang J, Huang R, et al. (2020) Clinical characteristics of a case series of children with coronavirus disease 2019. Pediatr Pulmonol 55: 1430-1432.

78. Zheng F, Liao C, Fan QH, et al. (2020) Clinical characteristics of children with coronavirus disease 2019 in hubei, china. Current Medical Science 40: 275-280.

79. Kotecha RS (2020) Challenges posed by COVID-19 to children with cancer. Lancet Oncol 21: e235.

80. Principi N, Bosis S, Esposito S (2020) Effects of coronavirus infections in children. Emerg Infect Dis 16: 183-188.

81. Choi SH, Kim HW, Kang JM, et al. (2020) Epidemiology and clinical features of coronavirus disease 2019 in children. Clin Exp Pediatr 63: 125-132.

82. Lou XX, Shi CX, Zhou CC, et al. (2020) Three children who recovered from novel coronavirus 2019 pneumonia. J Paediatr Child Health 56: 650-651.

83. Li W, Cui H, Li K, et al. (2020) Chest computed tomography in children with COVID-19 respiratory infection. Pediatr Radiol 50: 796-799.

84. Viner RM, Russell SJ, Croker H, et al. (2020) School closure and management practices during coronavirus outbreaks including COVID-19: A rapid systematic review. Lancet Child Adolesc Health 4: 397-404.

85. Rundle AG, Park Y, Herbstman JB, et al. (2020) COVID-19 related school closings and risk of weight gain among children. Obesity (Silver Spring) 28: 1008-1009.

86. Dalton L, Rapa E, Stein A (2020) Protecting the psychological health of children through effective communication about COVID-19. Lancet Child Adolesc Health 4: 346-347.

87. Cluver L, Lachman JM, Sherr L, et al. (2020) Parenting in a time of COVID-19. Lancet 95: e64.

88. Liu JJ, Bao Y, Huang X, et al. (2020) Mental health considerations for children quarantined because of COVID-19. Lancet Child Adolesc Health 4: 347-349.

89. Ni SQ, Fu QB, Shou XY, et al. (2020) Take precautions beforehand: Calling for clinical trials of pediatric drugs for treating coronavirus disease 2019. World J Pediatr 16: 275-277.

90. Wang Y, Zhu LQ (2020) Pharmaceutical care recommendations for antiviral treatments in children with coronavirus disease 2019. World J Pediatr 16: 271-274.

DOI: $10.36959 / 395 / 513$

Copyright: (C) 2020 HA JF. This is an open-access article distributed under the terms of the Creative Commons Attribution License, which permits unrestricted use, distribution, and reproduction in any medium, provided the original author and source are credited. 